SVERIGES RIKSBANK WORKING PAPER SERIES

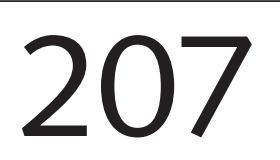

Financial Structure, Managerial Compensation and Monitoring

Vittoria Cerasi and Sonja Daltung JUNE 2007 
WORKING PAPERS ARE OBTAINABLE FROM

Sveriges Riksbank • Information Riksbank • SE-103 37 Stockholm Fax international: +4687870526

Telephone international: +4687870100

E-mail: info@riksbank.se

The Working Paper series presents reports on matters in the sphere of activities of the Riksbank that are considered to be of interest to a wider public.

The papers are to be regarded as reports on ongoing studies and the authors will be pleased to receive comments.

The views expressed in Working Papers are solely the responsibility of the authors and should not to be interpreted as reflecting the views of the Executive Board of Sveriges Riksbank. 


\title{
Financial structure, Managerial Compensation and Monitoring*
}

\author{
Vittoria Cerasi ${ }^{\dagger}$ and Sonja Daltung $\ddagger$ \\ Sveriges Riksbank Working Paper Series
}

No. 207

June 2007

\begin{abstract}
When a firm has external debt and monitoring by shareholders is essential, managerial bonuses are shown to be an optimal solution. A small managerial bonus linked to firm's performance not only reduces moral hazard between managers and shareholders, but also between creditors and monitoring shareholders. A negative relation between corporate bond yields and managerial bonuses can be predicted. Furthermore, the model shows how higher managerial pay-performance sensitivity goes hand in hand with greater company leverage and lower company diversification. These predictions find some support in the empirical literature.
\end{abstract}

Keywords: Managerial Compensation; Financial Structure; Monitoring; Diversification.

JEL classification: G320, M120

${ }^{*}$ We thanks Elena Carletti and Clara Graziano for there comments and seminar participants at Milan University (COFIN2003) We appreciate the excellent research assistance of Stefano Vezzoli. The views expressed in this paper are solely the responsibility of the authors and should not be interpreted as reflecting the views of the Executive Board of Sveriges Riksbank. Nor should the paper be interpreted as reflecting the views of the Ministry of Finance. When writing this paper Sonja Daltung was affiliated with the Research Department at Sveriges Riksbank.

${ }^{\dagger}$ Corresponding author: Università degli Studi di Milano Bicocca, Statistics Department, Via Bicocca degli Arcimboldi 8, 20126 Milano, Italy, vittoria.cerasi@unimib.it, phone: +39-02-6448-5821, fax: +39-02-6448-5878

${ }^{\ddagger}$ Ministry of Finance, Financial Institutions and Markets, Financial Law and Economics Division, S-103 33 Stockholm, Sweden, sonja.daltung@finance.ministry.se 


\section{Introduction}

In modern companies managers and shareholders together strive to enhance firm's value; they are, however, in competition when sharing the firm's revenues, not only internally, but also with outside investors (as pointed out by Jensen and Meckling, 1976). Designing the optimal managerial compensation has to account for this doubleedged competition. While managerial compensation improves managerial effort, it also reduces the amount of resources available to repay shareholders for their monitoring and bondholders for their investment in the firm. The impact of greater managerial compensation on company value crucially depends on the effect on all parties' incentives.

The interplay between managerial compensation and the financial structure of a firm is not new in literature (see Murphy,1999, for a review). We depart from such literature by explicitly introducing shareholders' monitoring for at least two reasons. First, shareholders' monitoring is as important as managerial effort to improve company value: for instance Core et al. (1999) find evidence that governance structures with greater control on managers improve company performance, while Huson et al. (2001) show that monitoring by shareholders increases the rate of replacement of managers in response to a poor company perfomance. Second, although managerial effort is essential, the empirical evidence on managerial compensation is controversial: for example Jensen and Murphy (1990) document that CEO pay-performance sensitivity is only $3.25 \$$ per $1000 \$$ change in shareholder value. This evidence questions the effectiveness of monetary incentives alone, without shareholders' monitoring, to enhance managerial effort.

In the model, managers strive to put in the essential effort but are subject to moral hazard: monetary incentives and shareholders' monitoring motivate their effort. Given that monitoring is unobservable, there is an additional moral hazard between shareholders and bondholders. In a leveraged firm, this moral hazard curtails insiders effort. Our findings show that shareholders in leveraged firms might find it optimal to pay a bonus to their managers in order to show bondholders a greater commitment towards monitoring. The direct effect of a larger managerial bonus is to increase the effort of the manager. However, when exerting greater effort, the manager reduces the likelihood of company bankruptcy; as a result, the incentive for shareholders to 
monitor increases in that they are residual claimants of any benefit from monitoring when the firm is solvent. Even a small managerial bonus helps to restore correct incentives for insiders, creating a virtuous circle, reducing the cost of external debt and enhancing total company value. This benefit is greater in leveraged and undiversified firms.

The implications of the model find empirical support in Duru et al.(2005) concerning the relation between managerial bonuses, corporate bond yields and leverage and in Rose and Shepard (1997) documenting a reduction in the managerial compensation as a consequence of increased corporate diversification.

The research outlined in this paper relates to the literature on managerial compensation and financial structure of the firm (John and John, 1993; Calcagno and Renneboog, 2006; Berkovitz et al., 2000). There the focus is on asset substitution efforts of insiders, while here the focus is on the monitoring effort of the owner. This has different implications for optimal managerial compensation. In the literature investigating asset substitution, shareholders and managers' interests are aligned through an increase in the pay-performance sensitivity of managerial compensation, by means of bonuses or stock-holdings. In a leveraged firm, greater pay-performance sensitivity of managerial compensation increases the cost of debt since bondholders anticipate the increased asset substitution attitude of managers; thus pay-performance sensitivity decreases with the level of debt. Here, instead, it is shown that a greater sensitivity to company revenues improves not only managerial effort, but - most importantly shareholders' monitoring, reinforcing insiders' incentives to exert extra effort. This has a positive consequence on the cost of debt. While a managerial bonus alone introduces a problem of competition for scarce resources between company insiders and outsiders, shareholders' monitoring helps to mitigate this competition.

The idea of efficiency wages (see Shapiro and Stiglitz, 1984, and subsequent papers) is here applied to managerial compensation schemes: managers' moral hazard is curbed through monetary incentives, but in addition shareholders monitor and punish their managers when any shirking is detected. This paper underlines the importance of insiders' monitoring as in the literature on shareholders' monitoring (see for instance Huddart, 1993; Aghion and Tirole, 1997; and Burkart et al., 1997). Although we share the opinion expressed in the literature that the efforts of shareholders and 
managers are both essential for the project, we differ in that we believe that the efforts are complementary, and we thus focus on the case of under- provision of monitoring.

Finally we share some insights with the literature on financial structure as incentive mechanism (Dewatripont and Tirole, 1994), and on debt as an optimal incentive mechanism when insiders exert unobservable effort (Innes, 1990; and Cerasi and Daltung, 2000). In this paper, we add the interaction between managerial effort and the efforts of the owners.

The remainder of the paper is organized as follows: Section 2 describes the basic model, Section 3 analyzes the equilibrium efforts and debt rate, and Section 4 presents optimal managerial compensation. Section 5 extends the basic model. The empirical predictions of the model are contained in Section 6, and concluding remarks are found in Section 7.

\section{The basic model}

Consider a two-date economy $(T=0,1)$ with three types of agents: entrepreneurs, investors and managers. An entrepreneur, without capital, starts up a risky project. Investors have capital to invest. A manager can enhance the success of the risky project. The entrepreneur hires the manager to run the project and raises funds from investors.

There are risky projects in the economy. Each project requires 1 unit of capital at date 0 and returns $R$ with probability $p$ at date 1 . Project returns are i.i.d. The success probability of each project depends on the combined efforts of the manager and the entrepreneur. We start by focusing on a single project firm and leave to Sub-section 5.2 the discussion of the role of diversification in the case of two projects.

The manager exerts an effort $e \in[0,1]$ at a private cost. A moral hazard is present in that the entrepreneur cannot observe the behavior of the manager without costs. The entrepreneur has access to a monitoring technology: by monitoring with intensity $m \in[0,1]$, he detects with probability $m$ misbehavior by his manager. The two efforts, monitoring and managerial effort, are costly and cannot be observed

outside the firm: the monitoring effort $\operatorname{costs} \frac{c_{1}}{2} m^{2}$ with $c_{1}>0$, while the managerial effort $\operatorname{costs} \frac{c_{2}}{2} e^{2}$ with $c_{2} \geq c_{1}>0$ since running a project requires more time than 
monitoring it. There is an additional moral hazard because investors cannot observe insiders' efforts.

The combined impact of the effort of the manager and of the monitoring of the entrepreneur is captured by the probability of success of the project. Managerial effort and monitoring effort are perfect substitutes and impact equally on the probability of success of the project: the probability reaches its maximum, $p_{H}$, when either the manager or the entrepreneur exert maximum effort on the project, and its minimum, $p_{L}<p_{H}$, when both effort levels are zero. The specific form of the probability derives from the outcome of the strategic interaction of the manager and of the entrepreneur, as it will become clear in the following Sub-section.

Without any effort, the expected return of the risky project is lower than the gross return from an alternative value preserving safe investment, i.e.,

$$
p_{L} R<1
$$

However, when either of the two agents exert maximum effort, the project return, net of the cost of effort, is greater than the alternative return:

$$
p_{H} R-\frac{c_{2}}{2}>1
$$

The timing of the model is as follows. At the beginning of date 0 , the entrepreneur sets the managerial compensation for the manager. Then the entrepreneur raises funds from perfectly competitive capital markets and entrepreneur and manager choose, respectively, monitoring effort $m$ and managerial effort $e$. Effort choices are not observable, while returns from the projects are observable to outsiders. At date 1 project returns are realized and claims are settled. Figure 1 summarizes the timing of the model.

\section{Insert Figure 1}

With this timing we assume that investors observe the managerial compensation. This assumption is common to other papers, as for instance in John and John (1993), and derives from the fact that public firms in the U.S. are obliged by the SEC to disclose compensation paid to managers.

The model is solved backwards: equilibrium effort, monitoring and return to investors are computed for given managerial compensation. Then, entrepreneur's optimal choice of managerial compensation is resolved. 


\subsection{Managerial compensation}

The manager, who responds to monetary incentives, is offered a managerial compensation. The managerial compensation is the sum of a fixed salary and a managerial bonus. The fixed salary is set at equal to the zero outside option of the manager. The managerial bonus $b \in[0, R]$ is by contract dependent on the observable return from the project and it is paid whenever the project succeeds. The entrepreneur retains the option to fire the manager, when, as a result of monitoring, he detects misbehavior by the manager. ${ }^{1}$ The project's probability of success is $p_{H}$ when the old manager is fired and a new manager is hired.

Figure 2 depicts the strategic interaction of the entrepreneur and of the manager.

\section{Insert Figure 2}

From Figure 2 we derive the form of the probability of success of the project:

$$
p=[m+e(1-m)] p_{H}+(1-m)(1-e) p_{L} .
$$

The probability of success is $p_{H}$ when either the manager or the entrepreneur exert effort, or when, as a result of monitoring, the manager is fired and another one is hired in his place; the probability is $p_{L}$ when the manager shirks without being detected. Once simplified, the probability of success becomes

$$
p=p_{H}-(1-e)(1-m) \Delta,
$$

with $\Delta \equiv p_{H}-p_{L}>0$. Figure 2 depicts the gross return for the entrepreneur and the manager, given their choices of effort. For given managerial compensation, the utility of the manager is

$$
u=q b-\frac{c_{2}}{2} e^{2},
$$

where $q=e p_{H}+(1-e)(1-m) p_{L}$ is the probability that the manager is rewarded the bonus. The manager chooses to exert effort with intensity $e$ : when he performs successfully, he earns the managerial bonus with probability $p_{H}$, otherwise with probability $p_{L}$. However, when he shirks his duties and the entrepreneur detects him, he

\footnotetext{
${ }^{1}$ The decision to fire the manager is at the entrepreneur's discretion. This is in line with the empirical fact that managerial contracts are riskier when compared to workers' labor contracts. In particular there is no "good cause" clause in the managerial contract, while this is required in the worker's contract.
} 
is fired with probability $m(1-e)$, and he is not paid the bonus. Notice that the probability of pocketing the managerial bonus is lower compared to the probability of success for the project, that is $q=p-m(1-e) p_{H}<p$. The reason is that, although the project might succeed, the manager will not earn the managerial bonus if caught shirking. However the new manager is paid the same bonus as the old manager. ${ }^{2}$

\subsection{Financing of the firm}

To start a project, an entrepreneur with $\omega$ units of inside equity issues $D=1-\omega$ units of debt on perfectly competitive financial markets. For each unit, the debt claim promises to pay a face value $r$ on date 1. Given the random return from the project net of the managerial bonus $Z$, the expected profit of the entrepreneur (the owner or the main shareholder of the firm) can be expressed as

$$
\pi=E \max \{Z-r D, 0\}-\omega-\frac{c_{1}}{2} m^{2},
$$

where the first term represents the expected total returns from the projects net of managerial bonus and after debt-holders have been repaid, the second term is the opportunity cost of entrepreneur's capital and the third term is the monitoring cost. Expression (3) shows that debt carries a bankruptcy risk. Since the entrepreneur is subject to limited liability but invests in a risky project, debt-holders may not obtain the promised face value. We can rewrite eq.(3) as

$$
\pi=p(R-b)-D[r-S]-\omega-\frac{c_{1}}{2} m^{2},
$$

where $[r-S] D=r D-E \max \{r D-Z, 0\}$ is the expected return to debt-holders, the difference between the debt rate $r$ and the expected shortfalls on the face value of debt $S=(1-p) r$. The expected shortfalls vary with monitoring and managerial effort in line with the probability of success of projects: greater monitoring and managerial effort lead to greater probability of honoring the debt and smaller expected shortfalls.

\footnotetext{
${ }^{2}$ This assumption guarantees that the entrepreneur will not fire the manager too often, given that the monitoring outcome is non-observable. After firing a manager, the entrepreneur hires another manager and pays him exactly the same bonus: thus he will not fire the old manager to save the bonus.
} 


\section{Equilibrium efforts and debt rate}

We now turn to the equilibrium effort choices, monitoring and managerial effort, and to the equilibrium debt rate, for a given managerial bonus $b$.

The entrepreneur and the manager choose simultaneously and non-cooperatively their efforts; then investors, anticipating the equilibrium efforts, set the debt rate accordingly. We characterize the symmetric equilibrium of the game in the following Proposition:

Proposition 1 For a given managerial bonus b, the symmetric equilibrium in which the manager exerts effort $\widehat{e}(b)$, the entrepreneur exerts monitoring effort $\widehat{m}(b)$ and pays to investors the debt rate $\widehat{r}(b)$, is characterized by the solution to the following equations:

$$
\begin{aligned}
{\left[\Delta+\widehat{m}(b) p_{L}\right] b-c_{2} \widehat{e}(b) } & =0 \\
(1-\widehat{e}(b)) \Delta(R-b)+D \frac{\partial \widehat{S}(b)}{\partial m}-c_{1} \widehat{m}(b) & =0 \\
\widehat{r}(b)-\widehat{S}(b) & =1 .
\end{aligned}
$$

where $D \frac{\partial \widehat{S}(b)}{\partial m}=-\widehat{r}(b) D(1-\widehat{e}(b)) \Delta$ and $\widehat{S}(b)=(1-\widehat{p}(b)) \widehat{r}(b)$.

Proof. See the appendix.

Eq.(5) shows that the effort of the manager increases when either the managerial bonus or monitoring increases; in other words, the managerial bonus and monitoring are substitutes to induce higher managerial effort.

Eq.(6) shows the moral hazard between the entrepreneur and investors. The moral hazard of external financing is captured by the negative sign of the second term, i.e., the derivative of the expected shortfalls with respect to monitoring: as the monitoring effort increases, the probability of success rises and this reduces the expected shortfalls. The marginal benefit of monitoring is partially appropriated by investors through a reduction in the expected shortfalls. Given that investors cannot observe the monitoring intensity, the debt rate will not be adjusted accordingly and this reduces the monitoring effort of the entrepreneur. The severity of this moral hazard depends on the size of expected shortfalls: expected shortfalls are reduced by increases in either managerial effort or entrepreneurial monitoring. 
Finally, eq.(7) shows that in equilibrium the expected return from risky debt must equal the alternative return 1.

Once we substitute the symmetric equilibrium efforts, monitoring and debt rate in eq.(4), the entrepreneur's profits are:

$$
\widehat{\pi}(b)=\widehat{p}(b)(R-b)-1-\frac{c_{1}}{2} \widehat{m}(b)^{2}
$$

where $\widehat{p}(b)=p_{H}-(1-\widehat{m}(b))(1-\widehat{e}(b)) \Delta$. We now turn to the optimal managerial compensation.

\section{Optimal managerial compensation}

In the first stage, the entrepreneur, who anticipates effort choices and debt rate, sets the level of the managerial bonus to maximize his profits in eq.(8). The entrepreneur finds it optimal to pay a managerial bonus whenever equilibrium profits increase with the bonus. We compare equilibrium profits without a bonus $\widehat{\pi}(0)$ to equilibrium profits in (8) and derive:

$$
\widehat{\pi}(b)-\widehat{\pi}(0)=R[\widehat{p}(b)-\widehat{p}(0)]-b \widehat{p}(b)-\frac{c_{1}}{2}\left(\widehat{m}(b)^{2}-\widehat{m}(0)^{2}\right) .
$$

The difference in profits depends upon three components: the difference in success probabilities, the direct impact of the bonus on total revenues and the difference in monitoring costs. Given that the managerial bonus has a direct negative effect on profits, a necessary condition for its optimality is that it has a positive impact on the probability of success. We have the following result.

Proposition 2 There exists a threshold value $\bar{m} \in(0,1)$ such that the probability of success with the managerial bonus is higher than without it, $\widehat{p}(b)>\widehat{p}(0)$, if the entrepreneur monitoring effort with the bonus $\widehat{m}(b)$ is greater than $\bar{m}$.

Proof. See the appendix.

Given the difficulty to find a closed-form solution for the equilibrium equations in (5)-(7) due to non-linearities, we use a numerical example to show cases in which profits might be higher with a managerial bonus than without it. Let us take a specific numerical example where the project is entirely financed through debt. We 
derive the equilibrium profits for different values of the managerial bonus when $p_{L}=$ $0.6, p_{H}=0.85, R=1.65, c_{1}=0.1$ and $c_{2}=0.35$. When the managerial bonus is $b=0$ in equilibrium the manager does not exert any effort, while the entrepreneur exerts an insufficient monitoring effort: profits are close to zero $\widehat{\pi}(0)=0.014$. If the managerial bonus is set to $b=0.06$, the manager exerts an effort $\widehat{e}(0.06)=0.11$ and the entrepreneur a monitoring effort $\widehat{m}(0.06)=0.67$ earning profits $\widehat{\pi}(0.06)=$ $0.215>0.014$. The result hinges on the beneficial effect of the bonus on the cost of external finance. Investors who observe the managerial bonus anticipate the increase in the success probability of the projects and ask for a lower debt rate. The debt rate falls from $\widehat{r}(0)=1.63$ to $\widehat{r}(0.06)=1.28$ with the managerial bonus. This reduces the share of revenues for investors and improves the entrepreneur's incentive to monitor.

The impact of a greater managerial bonus on the monitoring intensity in equilibrium can be separated into two effects, one negative, one positive. The negative effect stems from net project revenues: given the monitoring effort a higher managerial bonus implies a greater share of project returns to managers, thus improving manager's incentives and conversely reducing the incentives of the entrepreneur to monitor. The positive effect derives from the expected shortfalls: greater effort by the manager reduces the derivative of the shortfalls in eq.(6), thus strengthening monitoring incentives of the entrepreneur. There are cases where the positive effect dominates and monitoring increases.

Investors, anticipating that with the bonus the manager exerts a higher effort and that a smaller probability of default of the project increases the monitoring effort of the entrepreneur, demand a lower interest rate. This reduces the cost of the external finance and rises overall profits. The bonus serves as an optimal commitment to increase the monitoring effort of the entrepreneur. The crucial assumption for the result is that investors observe managerial compensation. The result in this paper offers an additional rationale for why this is beneficial for firms demanding external finance.

\section{$5 \quad$ Leverage and diversification}

The model shows the optimality of managerial bonuses as a way for the entrepreneur to commit to a higher level of monitoring level. This result depends on leverage and 
diversification.

\section{$5.1 \quad$ Greater leverage}

The optimal managerial bonus depends on the level of debt over total assets, i.e., the firm's leverage. Proposition 2 shows that the benefit of the managerial bonus may be important enough to achieve greater probability of success than without the managerial bonus. To see when this result occurs, we conduct some comparative statistics.

Proposition 3 The threshold $\bar{m} \in(0,1)$ decreases with the amount of debt $D$.

Proof. See the appendix.

As the level of debt increases, the problem of the moral hazard of the entrepreneur becomes more acute; at the equilibrium the level of monitoring decreases. This reduces equilibrium profits. An increase in the managerial bonus increases the managerial effort and thus ameliorates the moral hazard of the entrepreneur. This reduces the cost of the external finance and increases the equilibrium profits.

Figure 3 shows the entrepreneur's equilibrium monitoring effort, while Figure 4 entrepreneur's equilibrium profits, as functions of the managerial bonus for different levels of debt, $D=0$ and $D=1$.

\section{Insert Figure 3 and Figure 4}

The optimal managerial bonus is larger in firms with greater leverage. Conversely, the smaller the inside equity the greater the moral hazard of the entrepreneur: to induce monitoring the entrepreneur must pay managers a greater managerial bonus. Given that the managerial bonus is observable to investors, this implies a greater commitment to monitoring by the entrepreneur.

\subsection{Larger number of projects}

The optimal managerial bonus depends on the number of independent projects $D+\omega$. We extend the basic model to the case of 2 projects to see how the result on the optimality of the managerial bonus changes with greater diversification. ${ }^{3}$

\footnotetext{
${ }^{3}$ In the model, the increase in size coincides with greater diversification. In the real world, however, size and degree of diversification can be disentangled, since projects can be selected from
} 
To start 2 projects, an entrepreneur with $\omega$ units of inside equity issues $D=2-\omega$ units of debt on perfectly competitive markets. ${ }^{4}$ As before, for each unit, the debt claim promises to pay a face value $r$ on date 1 . The entrepreneur assignes each project to a different manager. The distribution of total returns from projects now is different from the model with a single project as the revenues come from the sum of two independent projects. Given total returns from projects, net of managerial bonus payments, $Z$, the expected profit of the entrepreneur can be expressed as

$$
\pi=\sum_{i=1}^{2} p_{i}(R-b)-D[r-S]-\omega-\frac{c_{1}}{2} \sum_{i=1}^{2} m_{i}^{2}, \quad i=1,2 .
$$

where the first term represents the expected total returns from the 2 projects net of the managerial bonus, the second term is the expected return to debt-holders, the third term is the opportunity cost of entrepreneur's capital and the last term is the sum of monitoring costs. The expected return to debt-holders is the difference between the debt rate $r$ and the expected shortfalls on the face value of debt $S$.

Similarly to the single project case, the symmetric equilibrium of the game is characterized by the equations in Proposition 1. The expressions of the expected shortfalls and their derivative with respect to monitoring are now different, given that the distribution of total returns from the 2 projects has changed compared to that of a single project (see Appendix - Part A - for the detailed expression of expected shortfalls and their derivative in this case).

In the following Proposition we show how the monitoring effort changes when the entrepreneur increases the number of projects, switching from a single project to two projects, for a given leverage.

Proposition 4 For a given leverage, the threshold $\bar{m} \in(0,1)$ increases with the number of projects.

Proof. See the appendix.

more or less correlated opportunities. See for instance Hellwig (1998) for a model where this choice is analyzed in a setting without delegation.

${ }^{4}$ While in the single project case debt and outside equity are equivalent financial contracts, this is not true anymore in the 2 projects case. Thus we use the result in Innes (1990) who shows that debt is the optimal solution when the entrepreneur exerts a non-observable and costly effort. 
For a given leverage, as the number of independent projects increases from 1 to 2 the optimal managerial bonus decreases. For instance in the same numerical example as that in Section 4, for the entrepreneur starting 2 projects instead of one project, the optimal bonus is 0.05 whereas it was 0.06 in the single project case. Notice that the entrepreneur has to issue 1 unit more of debt to fund the additional project: however the increased diversification reduces the moral hazard of the entrepreneur.

Given that the number of projects is observable by investors before signing the debt contract, increasing the number of projects has a commitment effect on the entrepreneur's monitoring. From eq.(6) the moral hazard of the entrepreneur depends on the size of the expected shortfalls on debt. As the number of independent projects increases, expected shortfalls and their derivative reduce. ${ }^{5}$ The derivative captures the moral hazard of the entrepreneur and decreases with the number of independent projects: in a diversified firm it will be very small. As the size of the firm increases, the incentive to monitor by the entrepreneur is stronger even without a managerial bonus. This mechanism is analyzed in Cerasi and Daltung (2000), where it is shown that, when the degree of diversification reduces variability in the distribution of project returns, lessening the probability of failure of the firm increases the incentive to monitor of the entrepreneur. Managerial bonuses and diversification are thus substitute mechanisms to strengthen insiders' incentives.

\section{Empirical implications}

The model has numerous empirical predictions on the level of managerial compensation. This paper shares with many others (e.g., John and John, 1993) the implication that managerial compensation and financial structure of the firm are to be studied together. This implication finds empirical support in Hartzell and Starcks (2003).

The model predicts that, once we control for the degree of diversification and leverage, firms paying higher managerial bonus to their managers have a lower cost of external debt. Evidence of a negative cross-sectional relation between managerial bonus and returns to bondholders is supportive of our model. Duru et al. (2005) find that larger managerial bonuses are associated with lower corporate bond yields and

\footnotetext{
${ }^{5}$ The property that expected shortfalls are smaller in the case of two projects is due to the Binomial distribution of total returns. In a more general case, according to the law of large numbers, it is possible to find a number of projects sufficiently large for the expected shortfalls to decrease.
} 
conclude that managerial bonuses help reduce the cost of external debt in contrast with the empirical evidence on the relation between managerial stock-holdings and bond yields (see, for instance, De Fusco et al., 1990, among others).

Another prediction of the model is that, once controls are set for firm size or degree of diversification, the higher the leverage, the greater the level of managerial bonus: as the acuteness of moral hazard increases, insiders shift the greater risk of default onto creditors due to limited liability. A greater managerial bonus serves to increase insiders' incentives. There is empirical evidence that more leveraged firms pay higher managerial bonuses to their managers. Again Duru et al. (2005) find that more leveraged firms tend to pay greater managerial bonuses to their managers. Other papers, such Mehran (1992) and Berger et al. (1997), point out that managers in more leveraged firms have greater pay-performance sensitivity compensation. Evidence in support of the model is that managers in firms owned by a small number of shareolders - i.e., closely held firms - are rewarded with lower bonuses as shareholders' incentives to monitor are greater. Core et al. (1999) report that CEO pay-performance sensitivity is lower in firms with larger numbers of monitoring shareholders. Edwards et al. (2006) find that pay-performance sensitivity measured on managerial bonuses decreases when there are large independent shareholders. Furthermore, in management buyouts, that is in LBOs where the same management runs the company, greater leverage is accompanied by the adoption of greater pay-performance incentives for managers (see Kaplan, 1989).

Finally, a prediction of the model is that more diversified firms should pay lower managerial bonuses, given that managerial bonuses and a higher degree of diversification are alternative mechanisms to improve insiders' incentives. Jensen and Murphy (1990) report empirical evidence that in larger firms the average sensitivity of managerial compensation to change in shareholders wealth is $1.85 \$$ compared with the figure of $8.05 \$$ in smaller firms. This prediction is in line with this evidence, when larger firms are also more diversified: Rose and Shepard (1997) show that changes in incumbent CEO compensation levels are negatively correlated with changes in the degree of corporate diversification. 


\section{Conclusion and extensions}

This paper analyses the optimal level of managerial bonus when firms are leveraged and non-diversified. When monitoring by shareholders is essential, although subject to moral hazard, managerial bonus provides a commitment to exert greater effort by insiders towards external claim-holders. The model predicts greater managerial pay-performance sensitivity, the greater the leverage and the lower the degree of diversification.

Throughout the analysis we have assumed that managers are paid out of project revenues before bondholders, namely that they are senior compared to other creditors. In the model with a single project this assumption is neutral, while it is crucial for the model with two projects. One possible effect of a different seniority of managerial bonuses is that managers could be punished not only when shirking, but also when the firm is unable to repay bondholders (see for instance John and John, 1993; and Calcagno and Renneboog, 2006). The optimal priority of claims structure is out of the scope of this paper and requires further investigation.

In the model with 2 projects we have assumed that each manager is assigned to a single risky project. Laux (2001) shows that assigning more than one project to each manager could be optimal, because it increases the set of states in which the entrepreneur can punish the manager. The interaction between internal hierarchy and managerial compensation is left to future research.

Finally, in this paper we have focused on managerial bonuses while ignoring other forms of pay-performance incentives, such as stock-options or direct stock-holdings to managers. Given our simple setup, where each manager is assigned to only one project and project returns are dichotomic, our bonus variable can be easily re-interpreted as managerial equity holdings. In a more general setup, we would have to distinguish between the different forms of managerial pay-performance compensation. 


\section{A Profits with 2 projects}

Total return on projects, net of managerial bonus payments, $Z$, has the Binomial distribution

$$
Z=\left\{\begin{array}{cc}
0 & \left(1-p_{i}\right)\left(1-p_{-i}\right) \\
R-b & p_{i}\left(1-p_{-i}\right)+p_{-i}\left(1-p_{i}\right) \\
2(R-b) & p_{i} p_{-i}
\end{array}\right.
$$

and average equal to

$$
E(Z)=\left(p_{i}+p_{-i}\right)(R-b),
$$

where $p_{i}$ is given by $(1), i \in\{1,2\}$ and $i \neq-i$. The expected profit is

$$
\pi=E \max \{Z-r D, 0\}-\omega-\frac{c_{1}}{2} \sum_{i=1}^{2} m_{i}^{2} .
$$

This can be rewritten using the transformation $\max \{0, x\}=x+\max \{0,-x\}$ as

$$
\pi=E(Z)-r D+E \max \{r D-Z, 0\}-\omega-\frac{c_{1}}{2} \sum_{i=1}^{2} m_{i}^{2} .
$$

This expression simplifies to (10) once we substitute (11) and $[r-S] D=r D-$ $E \max \{r D-Z, 0\}$, where $S$ is given by

$$
S=r\left(1-p_{i}\right)\left(1-p_{-i}\right)+\frac{1}{D} \max \{r D-(R-b), 0\}\left[p_{i}\left(1-p_{-i}\right)+p_{-i}\left(1-p_{i}\right)\right] .
$$

For a given managerial bonus $b$, face value $r$ and managerial effort $e_{i}$ the entrepreneur chooses the monitoring intensity to maximize profits in (10), that is

$$
\frac{\partial \pi}{\partial m_{i}}=\left(1-e_{i}\right) \Delta(R-b)+D \frac{\partial S}{\partial m_{i}}-c_{1} m_{i}=0, \quad i=1,2 .
$$

with

$$
D \frac{\partial S}{\partial m_{i}}=\left[\max \{r D-(R-b), 0\}\left(1-2 p_{-i}\right)-r D\left(1-p_{-i}\right)\right]\left(1-e_{i}\right) \Delta .
$$

For a given managerial bonus $b$, debt rate $r$ and monitoring intensity $m_{i}$, each manager chooses the effort to maximize his utility in (2):

$$
\frac{\partial u_{i}}{\partial e_{i}}=\left(\Delta+m_{i} p_{L}\right) b-c_{2} e_{i}=0, \quad i=1,2 .
$$

The Nash equilibrium is given by the solution to (12) and (13). In the symmetric Nash equilibrium $e_{i}=e_{-i}=\widehat{e}(b)$ and $m_{i}=m_{-i}=\widehat{m}(b)$. The system of equations that defines the symmetric equilibrium, collapses to the system of equations (5)-(7) with

$$
\begin{gathered}
D \frac{\partial \widehat{S}(b)}{\partial m_{i}}=[\max \{\widehat{r}(b) D-(R-b), 0\}(1-2 \widehat{p}(b))-\widehat{r}(b) D(1-\widehat{p}(b))](1-\widehat{e}(b)) \Delta . \\
\widehat{S}(b)=\widehat{r}(b)(1-\widehat{p}(b))^{2}+\frac{2}{D} \max \{\widehat{r}(b) D-(R-b), 0\} \widehat{p}(b)(1-\widehat{p}(b))
\end{gathered}
$$




\section{B Proofs}

Proof of Proposition 1: For a given managerial bonus $b$, face value $r$ and managerial effort $e$ the entrepreneur chooses the monitoring intensity to maximize profits in (4), that is

$$
\frac{\partial \pi}{\partial m}=(1-e) \Delta(R-b)+D \frac{\partial S}{\partial m}-c_{1} m=0
$$

with

$$
D \frac{\partial S}{\partial m}=-r D(1-e) \Delta
$$

For a given managerial bonus $b$, debt rate $r$ and monitoring intensity $m$, each manager chooses the effort to maximize his utility in (2):

$$
\frac{\partial u}{\partial e}=\left(\Delta+m p_{L}\right) b-c_{2} e=0
$$

The Nash equilibrium is given by the couple of efforts $\{\widehat{m}(b), \widehat{e}(b)\}$ solution to (16) and (17). In addition investors require their expected return to be equal to 1 , that is $[r-S] D=D$. They rationally anticipate that the equilibrium effort is $\widehat{e}(b)$ and monitoring $\widehat{m}(b)$ for a given managerial bonus $b$. Substituting equilibrium efforts in the investors' rationality condition gives $(7)$.

Proof of Proposition 2: From equilibrium conditions in Proposition 1, substituting (7) into (6) gives

$$
\Delta\left[R-\frac{D}{\widehat{p}(b)}\right]=c_{1} \frac{\widehat{m}(b)}{(1-\widehat{e}(b))}+b \Delta
$$

where $\widehat{p}(b)=p_{H}-(1-\widehat{m}(b))(1-\widehat{e}(b)) \Delta$. When $b=0$ the above condition collapses to

$$
\Delta\left[R-\frac{D}{\widehat{p}(0)}\right]=c_{1} \widehat{m}(0)
$$

with $\widehat{p}(0)=p_{H}-(1-\widehat{m}(0)) \Delta$ since $\widehat{e}(0)=0$. We can compare $\widehat{p}(0)$ and $\widehat{p}(b)$ by using (18) and (19). It follows that $\widehat{p}(b)>\widehat{p}(0)$ if

$$
\frac{\widehat{m}(b)}{(1-\widehat{e}(b))}+\frac{b}{c_{1}} \Delta>\widehat{m}(0)
$$

It is useful to define the LHS of the above disequality, after substituting (5), as a generic function of $m \in[0,1]$

$$
g(m)=\frac{m}{1-\frac{b}{c_{2}}\left(\Delta+m p_{L}\right)}+\frac{b}{c_{1}} \Delta .
$$

The function $g(m)$ takes values $g(0)=\frac{b}{c_{1}} \Delta$ and $g(1)=\frac{1}{1-\frac{b}{c_{2}} p_{H}}+\frac{b}{c_{1}} \Delta>\frac{b}{c_{1}} \Delta$ and it increases monotonically in $m$. Thus there must exists a value $\bar{m}$ such that $g(\bar{m})=$ 
$\widehat{m}(0)$. This implies that $\widehat{p}(b)<\widehat{p}(0)$ if $\widehat{m}(b)<\bar{m}$ and $\widehat{p}(b)>\widehat{p}(0)$ if $\widehat{m}(b) \geq \bar{m}$ where $\bar{m} \equiv g^{-1}(\widehat{m}(0))$.

Proof of Proposition 3: From the proof of Proposition 2, $\bar{m}$ is defined as $\bar{m}=$ $g^{-1}(\widehat{m}(0))$. Since $g(m)$ is an increasing monotonic function, $\bar{m}$ behaves like this as well. It follows that $\bar{m}$ increases with $\widehat{m}(0)$. From equation (19) it can be easily seen that $\widehat{m}(0)$ decreases with $D$.

Proof of Proposition 4: In the case of a single project the entrepreneur issues $D_{1}=1-\omega_{1}$ units of debt, while in the case of 2 projects $D_{2}=2-\omega_{2}$. To mantain constant the leverage, i.e., the ratio between debt and total assets, it must be that

$$
\frac{D_{1}}{D_{1}+\omega_{1}}=\frac{D_{2}}{D_{2}+\omega_{2}}
$$

from which $D_{2}=2 D_{1}$ and $\omega_{2}=2 \omega_{1}$. The proof requires to compare the threshold in Proposition 2 with a new threshold in the case of 2 projects. We have to distinguish between two cases, depending on whether $\widehat{r}(b) D_{2}$ is above or below $(R-b)$.

Case (i): $\widehat{r}(b) D_{2}<R-b$. Then (14) becomes:

$$
D_{2} \frac{\partial \widehat{S}(b)}{\partial m_{i}}=-\widehat{r}(b) D_{2}(1-\widehat{p}(b))(1-\widehat{e}(b)) \Delta,
$$

while in this case (15) is:

$$
\widehat{S}(b)=\widehat{r}(b)(1-\widehat{p}(b))^{2} .
$$

Thus (6) and (7) simplify respectively to:

$$
\begin{aligned}
(1-\widehat{e}(b)) \Delta\left[(R-b)-\widehat{r}(b) D_{2}(1-\widehat{p}(b))\right]-c_{1} \widehat{m}(b) & =0 \\
\widehat{r}(b) \widehat{p}(b)(2-\widehat{p}(b)) & =1 .
\end{aligned}
$$

Substituting (21) in (20) gives:

$$
\Delta\left[R-D_{2} \frac{(1-\widehat{p}(b))}{\widehat{p}(b)(2-\widehat{p}(b))}\right]=c_{1} \frac{\widehat{m}(b)}{(1-\widehat{e}(b))}+b \Delta,
$$

where $\widehat{p}(b)=p_{H}-(1-\widehat{m}(b))(1-\widehat{e}(b)) \Delta$. When $b=0$ the above condition collapses to

$$
\Delta\left[R-D_{2} \frac{(1-\widehat{p}(0))}{\widehat{p}(0)(2-\widehat{p}(0))}\right]=c_{1} \widehat{m}_{2}(0)
$$

with $\widehat{p}(0)=p_{H}-\left(1-\widehat{m}_{2}(0)\right) \Delta$ since $\widehat{e}(0)=0$. We can compare $\widehat{p}(0)$ and $\widehat{p}(b)$ by using $(22)$ and (23). It follows that $\widehat{p}(b)>\widehat{p}(0)$ if

$$
\frac{\widehat{m}(b)}{(1-\widehat{e}(b))}+\frac{b}{c_{1}} \Delta>\widehat{m}_{2}(0) \text {. }
$$


The LHS of the above disequality can be defined as the same generic function $g(m)$ as that in Proposition 2. Given that the function $g(m)$ is monotonically increasing in $m$, there must exists a value $\bar{m}_{2}$ such that $\widehat{p}(b)>\widehat{p}(o)$ if $\widehat{m}(b) \geq \bar{m}_{2}$ where $\bar{m}_{2} \equiv g^{-1}\left(\widehat{m}_{2}(0)\right)$. We can compare $\bar{m}_{2}$ to the $\bar{m}$ in Proposition 2. Notice that the function $g($.$) is the same in both cases and it is monotonically increasing. It is easy$ to see that $\widehat{m}_{2}(0)>\widehat{m}(0)$ by comparing (19) to (23). Then it follows that $\bar{m}_{2}>\bar{m}$.

Case (ii): $\widehat{r}(b) D_{2}>R-b$. Then (14) becomes:

$$
D_{2} \frac{\partial \widehat{S}(b)}{\partial m_{i}}=-\left[\widehat{r}(b) D_{2} \widehat{p}(b)+(R-b)(1-2 \widehat{p}(b))\right](1-\widehat{e}(b)) \Delta,
$$

while in this case (15) is

$$
\widehat{S}(b)=\widehat{r}(b)(1-\widehat{p}(b))^{2}+\frac{2}{D_{2}}\left[\widehat{r}(b) D_{2}-(R-b)\right] \widehat{p}(b)(1-\widehat{p}(b)) .
$$

Thus (6) and (7) simplify respectively to:

$$
\begin{aligned}
(1-\widehat{e}(b)) \Delta\left[2(R-b)-\widehat{r}(b) D_{2}\right] \widehat{p}(b)-c_{1} \widehat{m}(b) & =0, \\
\widehat{r}(b) \widehat{p}(b)^{2}+\frac{2}{D_{2}}(R-b) \widehat{p}(b)(1-\widehat{p}(b)) & =1 .
\end{aligned}
$$

Substituting (25) in (24) gives:

$$
\Delta\left[2 R-\frac{D_{2}}{\widehat{p}(b)}\right]=c_{1} \frac{\widehat{m}(b)}{(1-\widehat{e}(b))}+2 b \Delta,
$$

where $\widehat{p}=p_{H}-(1-\widehat{m})(1-\widehat{e}) \Delta$. When $b=0$ the above condition collapses to

$$
\Delta\left[2 R-\frac{D_{2}}{\widehat{p}(0)}\right]=c_{1} \widehat{m}_{2}(0),
$$

with $\widehat{p}(0)=p_{H}-\left(1-\widehat{m}_{2}(0)\right) \Delta$. We can compare $\widehat{p}(b)$ and $\widehat{p}(0)$ by using (26) and (27). It follows that $\widehat{p}(b)>\widehat{p}(0)$ if

$$
\frac{\widehat{m}(b)}{(1-\widehat{e}(b))}+2 \frac{b}{c_{2}} \Delta>\widehat{m}_{2}(0) .
$$

It is useful to define the LHS of the above disequality, after substituting (5), as a generic function of $m \in[0,1]$

$$
h(m)=\frac{m}{1-\frac{b}{c_{2}}\left(\Delta+m p_{L}\right)}+2 \frac{b}{c_{1}} \Delta=g(m)+\frac{b}{c_{1}} \Delta .
$$

The function $h(m)$ takes values $h(0)=2 \frac{b}{c_{1}} \Delta$ and $h(1)=\frac{1}{1-\frac{b}{c_{2}} p_{H}}+2 \frac{b}{c_{1}} \Delta>2 \frac{b}{c_{1}} \Delta$ and it increases monotonically in $m$. Thus there must exists a value $\bar{m}_{2}$ such that $h\left(\bar{m}_{2}\right)=\widehat{m}_{2}(0)$. This implies that $\widehat{p}(b)>\widehat{p}(0)$ if $\widehat{m}(b) \geq \bar{m}_{2}$ where $\bar{m}_{2} \equiv h^{-1}\left(\widehat{m}_{2}(0)\right)=$ $g^{-1}\left(\widehat{m}_{2}(0)-\frac{b}{c_{1}} \Delta\right)$. It is easy to see that $\widehat{m}_{2}(0)=2 \widehat{m}(0)$ by comparing (19) to (27). For $\bar{m}_{2}>\bar{m}$ it must be that $\left(2 \widehat{m}(0)-\frac{b}{c_{1}} \Delta\right)>\widehat{m}(0)$. Given that $\widehat{m}(0)=$ $\frac{\Delta}{c_{1}}\left[R-r D_{1}\right]$ when $\left(R-r D_{1}\right)>b$, i.e., when the bonus is sufficiently small not to cause bankruptcy of the single project firm, it follows that $\bar{m}_{2}>\bar{m}$. 


\section{References}

[1] Aghion P., Tirole J. (1997), Real and Formal Authority in Organizations, Journal of Political Economy, 105 (1), 1-29.

[2] Berger P., Ofek E., Yermak D. (1997), Managerial Entrenchment and Capital Structure Decisions, Journal of Finance, 52, 1411-1438.

[3] Berkovitz E., Israel R., Spiegel Y. (2000), Managerial Compensation and Capital Structure, Journal of Economics \& Management Strategy, 9(4), 549-584.

[4] Burkart M., Gromb D., Panunzi F. (1997), Large Shareholders, Monitoring and the Value of the Firm, Quarterly Journal of Economics, 112, 693-728.

[5] Calcagno R., Renneboog L. (2006), Capital Structure and Managerial Compensation: the Effects of Remuneration Seniority, Journal of Banking and Finance, forthcoming.

[6] Cerasi V., Daltung S. (2000), The Optimal Size of a Bank: Costs and Benefits of Diversification, European Economic Review, 44 (9), 1701-1726.

[7] Core J., Holthausen R., Larcker D. (1999), Corporate Governance, Chief Executive Officer Compensation, and Firm Performance, Journal of Financial Economics, 51, 371-406.

[8] De Fusco R., Johnson R., Zorn T. (1990), The Effect of Executive Stock-Option Plans on Stockholders and Bondholders, Journal of Finance, 45, 617-628.

[9] Dewatripont M., Tirole J. (1994), A Theory of Debt and Equity: Diversity of Security and Manager-Shareholders Congruence, Quarterly Journal of Economics, 109, 1027-1054.

[10] Duru A., Mansi S.,Reeb D. (2005), Earnings-Based Bonus Plans and the Agency Costs of Debt, Journal of Accounting and Public Policy, 24, 431-447.

[11] Edwards J., Eggert W., Welchenrieder A. (2006), The Measurement of Firm Ownership and its Effect on Managerial Pay, CESIfo Working Paper No.1774.

[12] Hartzell J., Starcks L. (2003), Institutional Investors and Executive Compensation, Journal of Finance, 58(6), 2351-2374.

[13] Hellwig M. (1998), Allowing for Risky Choices in Diamond's Model of Financial Intermediation as Delegated Monitoring, SFB Working Paper N. 98-04, University of Mannheim, Mannheim. 
[14] Huson M., Parrino R., Starks L. (2001), Internal Monitoring Mechanisms and CEO Turnover: A Long Term Perspective, Journal of Finance, 56(6), 2265-2297.

[15] Huddart S. (1993), The Effect of a Large Shareholder on Corporate Value, Management Science, 39(11), 1407-1421.

[16] Innes R.D. (1990), Limited Liability and Incentive Contracting with Ex-ante Action Choices, Journal of Economic Theory, 52, 45-67.

[17] Kaplan S. (1989), The Effects of Management Buyouts on Operating Performance and Value, Journal of Financial Economics, 24(2), 217-254.

[18] Laux C. (2001), Limited-liability and Incentive Contracting with Multiple Projects, RAND Journal of Economics, 32 (3), 514-526.

[19] Jensen M.C., Meckling W. (1976), Theory of the Firm: Managerial Behavior, Agency Costs and Ownership Structure, Journal of Financial Economics, 3, 305-360.

[20] Jensen M.C., Murphy K.J. (1990), Performance Pay and Top-Management Incentives, Journal of Political Economy, 98(2), 225-264.

[21] John T., John K. (1993), Top-Management Compensation and Capital Structure, Journal of Finance, 48(3), July, 949-974.

[22] Mehran H.(1992), Incentive Executive Plans, Corporate Control and Capital Structure, Journal of Financial and Quantitative Analysis, 27(4), 539-560.

[23] Murphy K.J.(1999), Executive Compensation, in Handbook of Labor Economics, O. Ashenfelter and D. Card eds., Vol.3B, Chap.38, Elsevier.

[24] Rose N., Shepard A. (1997), Firm Diversification and CEO Compensation: Managerial Ability or Executive Entrenchment?, RAND Journal of Economics, 28(3), 489-514.

[25] Shapiro C., Stiglitz J. (1984), Equilibrium Unemployment as a Worker Discipline Device, American Economic Review, 74(3), 433-444. 
Figure 1: Timing of the game.

\begin{tabular}{cccc}
$\mathrm{T}=0$ & & $\mathrm{~T}=1$ \\
\hline $\mid$ & $\mid$ & $\mid$ & $\mid$ \\
entrepreneur & contract with & entrepreneurs and & projects \\
sets & investors & managers & mature; \\
managerial & is signed & choose & claims \\
compensation & & efforts & are settled
\end{tabular}




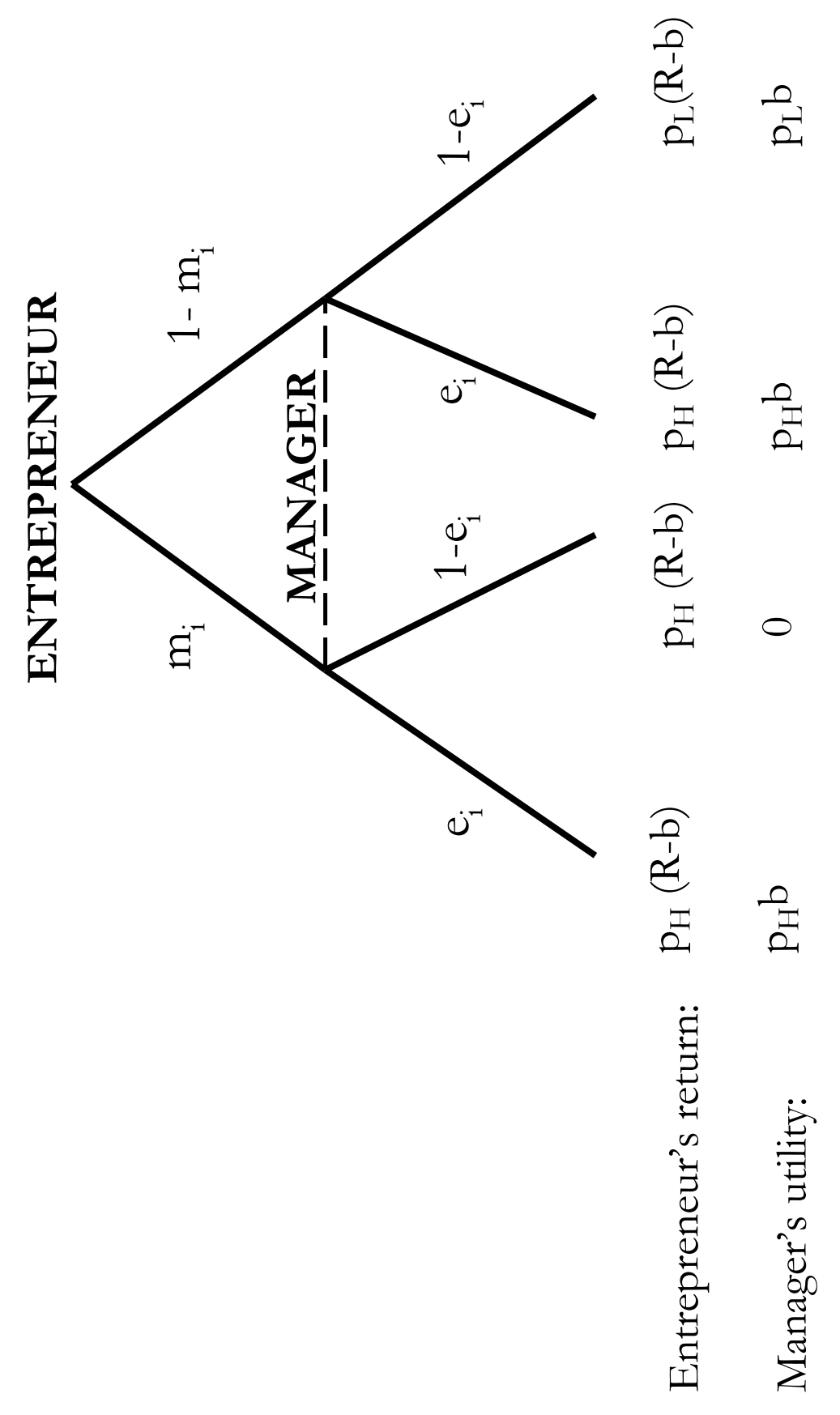

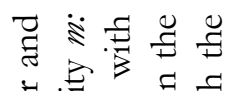

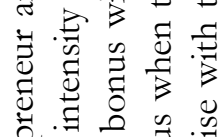

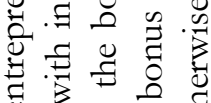

o

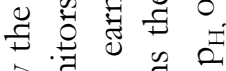

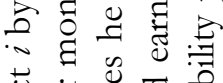

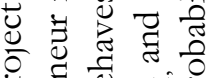

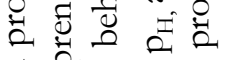

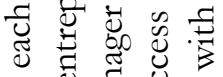

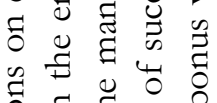

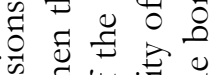

惫声出: 步

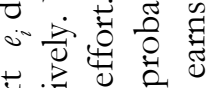

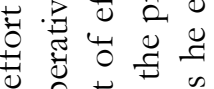

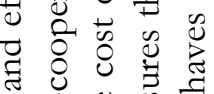

इ

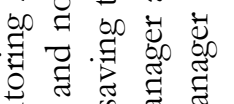

范宓颀

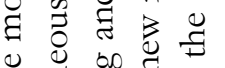

影

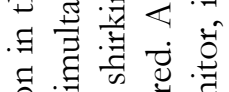

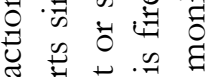

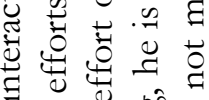

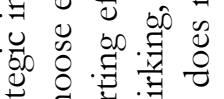

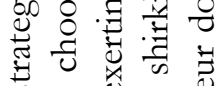

क w

范

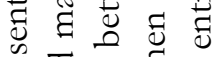

递㤩

可记它

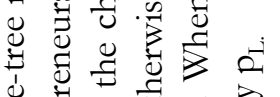

㟧

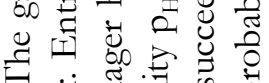

F

त)

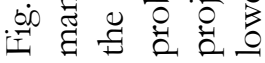




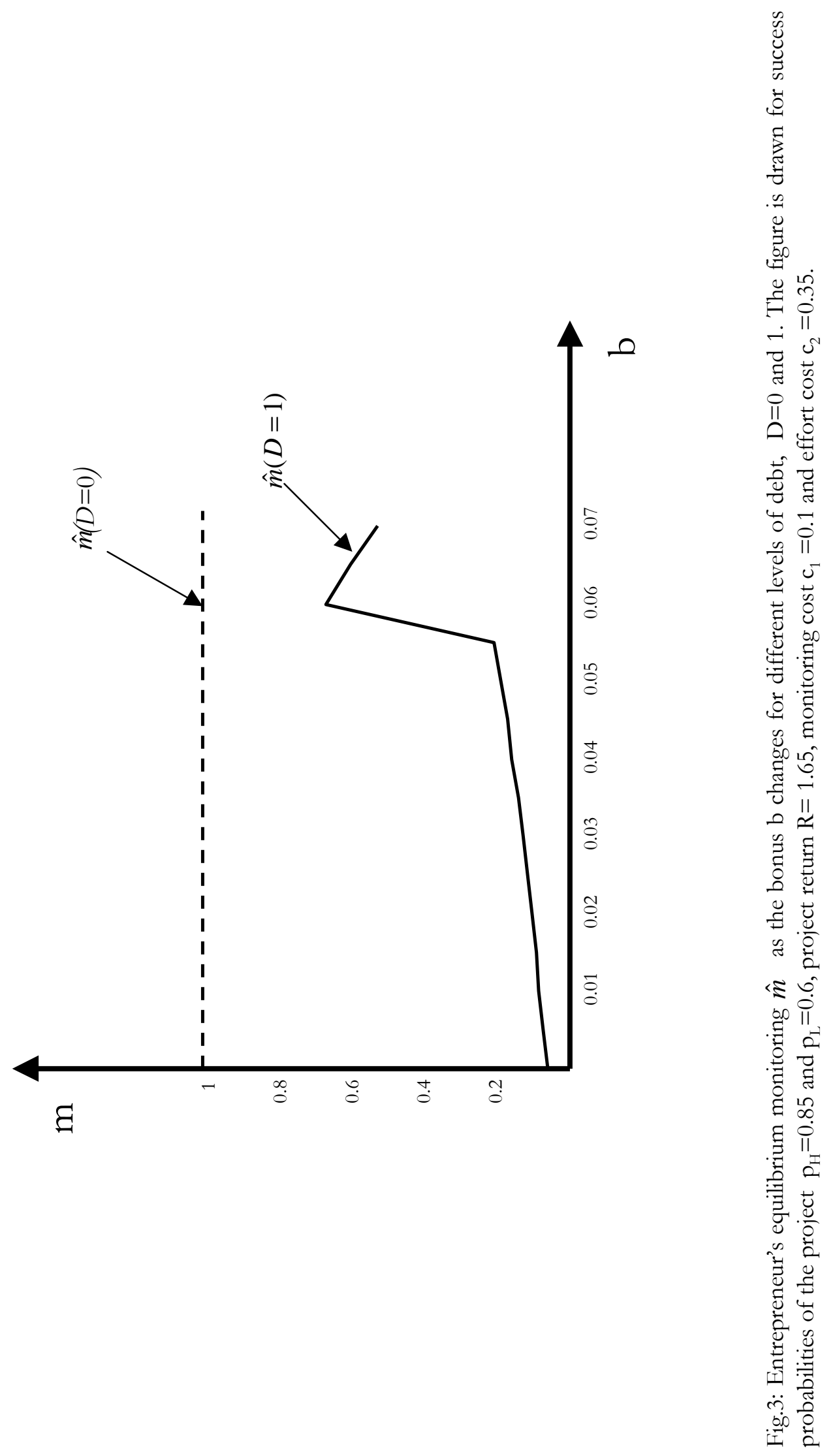




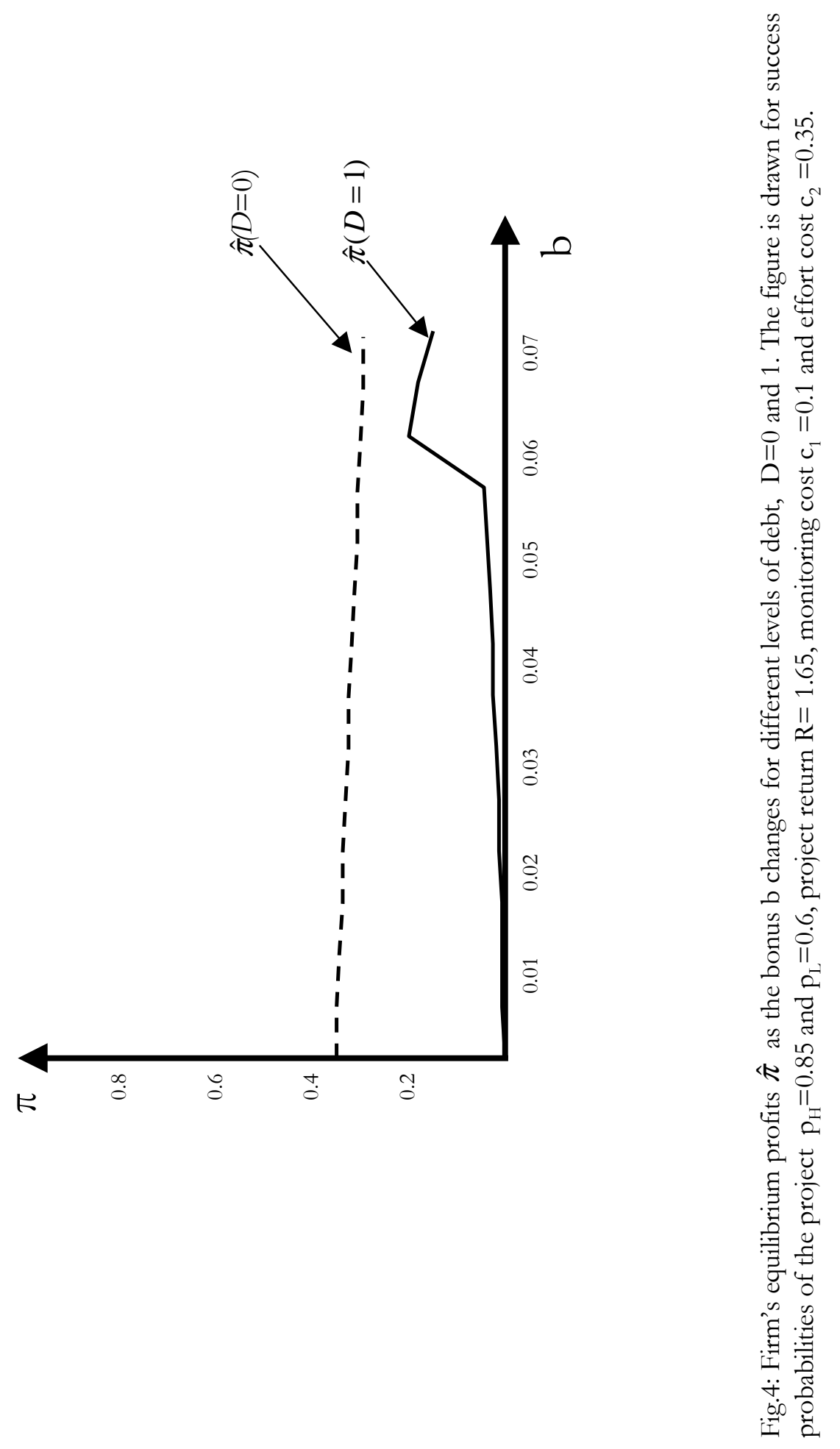




\section{Earlier Working Papers:}

For a complete list of Working Papers published by Sveriges Riksbank, see www.riksbank.se

Evaluating Implied RNDs by some New Confidence Interval Estimation Techniques

by Magnus Andersson and Magnus Lomakka....

Taylor Rules and the Predictability of Interest Rates

by Paul Söderlind, Ulf Söderström and Anders Vredin ......................................................... 2003:147

Inflation, Markups and Monetary Policy

by Magnus Jonsson and Stefan Palmqvist.....

Financial Cycles and Bankruptcies in the Nordic Countries by Jan Hansen........................................ 2003:149

Bayes Estimators of the Cointegration Space by Mattias Villani .................................................. 2003:150

Business Survey Data: Do They Help in Forecasting the Macro Economy?

by Jesper Hansson, Per Jansson and Mårten Löf

The Equilibrium Rate of Unemployment and the Real Exchange Rate:

An Unobserved Components System Approach by Hans Lindblad and Peter Sellin ........................ 2003:152

Monetary Policy Shocks and Business Cycle Fluctuations in a

Small Open Economy: Sweden 1986-2002 by Jesper Lindé

Bank Lending Policy, Credit Scoring and the Survival of Loans by Kasper Roszbach .......................... 2003:154

Internal Ratings Systems, Implied Credit Risk and the Consistency of Banks' Risk

Classification Policies by Tor Jacobson, Jesper Lindé and Kasper Roszbach .................................. 2003:155

Monetary Policy Analysis in a Small Open Economy using Bayesian Cointegrated

Structural VARs by Mattias Villani and Anders Warne

Indicator Accuracy and Monetary Policy: Is Ignorance Bliss? by Kristoffer P. Nimark ........................ 2003:157

Intersectoral Wage Linkages in Sweden by Kent Friberg .......................................................... 2003:158

Do Higher Wages Cause Inflation? by Magnus Jonsson and Stefan Palmqvist ............................. 2004:159

Why Are Long Rates Sensitive to Monetary Policy by Tore Ellingsen and Ulf Söderström .................. 2004:160

The Effects of Permanent Technology Shocks on Labor Productivity

and Hours in the RBC model by Jesper Lindé........................................................................ 2004:161

Credit Risk versus Capital Requirements under Basel II: Are SME Loans and Retail

Credit Really Different? by Tor Jacobson, Jesper Lindé and Kasper Roszbach

Exchange Rate Puzzles: A Tale of Switching Attractors

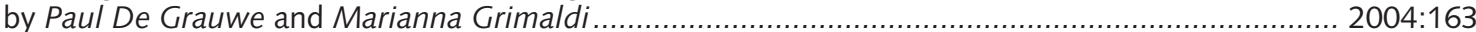

Bubbles and Crashes in a Behavioural Finance Model

by Paul De Grauwe and Marianna Grimaldi.

Multiple-Bank Lending: Diversification and Free-Riding in Monitoring

by Elena Carletti, Vittoria Cerasi and Sonja Daltung.............................................................. 2004:165

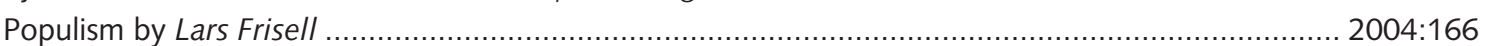

Monetary Policy in an Estimated Open-Economy Model with Imperfect Pass-Through

by Jesper Lindé, Marianne Nessén and Ulf Söderström

Is Firm Interdependence within Industries Important for Portfolio Credit Risk?

by Kenneth Carling, Lars Rönnegård and Kasper Roszbach

$2004: 168$

How Useful are Simple Rules for Monetary Policy? The Swedish Experience

by Claes Berg, Per Jansson and Anders Vredin

The Welfare Cost of Imperfect Competition and Distortionary Taxation

by Magnus Jonsson

A Bayesian Approach to Modelling Graphical Vector Autoregressions

by Jukka Corander and Mattias Villani

Do Prices Reflect Costs? A study of the price- and cost structure of retail payment

services in the Swedish banking sector 2002 by Gabriela Guibourg and Biörn Segendorf

Excess Sensitivity and Volatility of Long Interest Rates: The Role of Limited

Information in Bond Markets by Meredith Beechey.

State Dependent Pricing and Exchange Rate Pass-Through

by Martin Flodén and Fredrik Wilander.

The Multivariate Split Normal Distribution and Asymmetric Principal

Components Analysis by Mattias Villani and Rolf Larsson

Firm-Specific Capital, Nominal Rigidities and the Business Cycle

by David Altig, Lawrence Christiano, Martin Eichenbaum and Jesper Lindé

Estimation of an Adaptive Stock Market Model with Heterogeneous Agents by Henrik Amilon ........ 2005:177

Some Further Evidence on Interest-Rate Smoothing: The Role of Measurement

Errors in the Output Gap by Mikael Apel and Per Jansson...... 
Bayesian Estimation of an Open Economy DSGE Model with Incomplete Pass-Through

by Malin Adolfson, Stefan Laséen, Jesper Lindé and Mattias Villani.....

Are Constant Interest Rate Forecasts Modest Interventions? Evidence from

an Estimated Open Economy DSGE Model of the Euro Area by Malin Adolfson,

Stefan Laséen, Jesper Lindé and Mattias Villani

2005:180

Inference in Vector Autoregressive Models with an Informative

Prior on the Steady State by Mattias Villani.

2005:181

Bank Mergers, Competition and Liquidity by Elena Carletti, Philipp Hartmann

and Giancarlo Spagnolo ....

Testing Near-Rationality using Detailed Survey Data

by Michael F. Bryan and Stefan Palmqvist.

2005:183

Exploring Interactions between Real Activity and the Financial Stance

by Tor Jacobson, Jesper Lindé and Kasper Roszbach.

Two-Sided Network Effects, Bank Interchange Fees,

and the Allocation of Fixed Costs by Mats A. Bergman

Trade Deficits in the Baltic States: How Long Will the Party Last?

by Rudolfs Bems and Kristian Jönsson..... 2005:186

Real Exchange Rate and Consumption Fluctuations follwing Trade Liberalization

by Kristian Jönsson

Modern Forecasting Models in Action: Improving Macroeconomic Analyses at Central Banks

by Malin Adolfson, Michael K. Andersson, Jesper Lindé, Mattias Villani and Anders Vredin .......... 2005:188

Bayesian Inference of General Linear Restrictions on the Cointegration Space by Mattias Villani ..... 2005:189

Forecasting Performance of an Open Economy Dynamic Stochastic General Equilibrium Model

by Malin Adolfson, Stefan Laséen, Jesper Lindé and Mattias Villani....

2005:190

Forecast Combination and Model Averaging using Predictive Measures

by Jana Eklund and Sune Karlsson

Swedish Intervention and the Krona Float, 1993-2002

by Owen F. Humpage and Javiera Ragnartz 2006:192

A Simultaneous Model of the Swedish Krona, the US Dollar and the Euro

by Hans Lindblad and Peter Sellin 2006:193

Testing Theories of Job Creation: Does Supply Create Its Own Demand?

by Mikael Carlsson, Stefan Eriksson and Nils Gottfries....

2006:194

Down or Out: Assessing The Welfare Costs of Household Investment Mistakes

by Laurent E. Calvet, John Y. Campbell and Paolo Sodini

2006:195

Efficient Bayesian Inference for Multiple Change-Point and Mixture Innovation Models

by Paolo Giordani and Robert Kohn 2006:196

Derivation and Estimation of a New Keynesian Phillips Curve in a Small Open Economy

by Karolina Holmberg. 2006:197

Technology Shocks and the Labour-Input Response: Evidence from Firm-Level Data

by Mikael Carlsson and Jon Smedsaas 2006:198

Monetary Policy and Staggered Wage Bargaining when Prices are Sticky

by Mikael Carlsson and Andreas Westermark.

The Swedish External Position and the Krona by Philip R. Lane 2006:200

Price Setting Transactions and the Role of Denominating Currency in FX Markets

by Richard Friberg and Fredrik Wilander

The geography of asset holdings: Evidence from Sweden

by Nicolas Coeurdacier and Philippe Martin

Evaluating An Estimated New Keynesian Small Open Economy Model

by Malin Adolfson, Stefan Laséen, Jesper Lindé and Mattias Villani .....

The Use of Cash and the Size of the Shadow Economy in Sweden

by Gabriela Guibourg and Björn Segendorf

Bank supervision Russian style: Evidence of conflicts between micro- and macro-

prudential concerns by Sophie Claeys and Koen Schoors

Optimal Monetary Policy under Downward Nominal Wage Rigidity

by Mikael Carlsson and Andreas Westermark. 2007:206 
Website: www.riksbank.se 